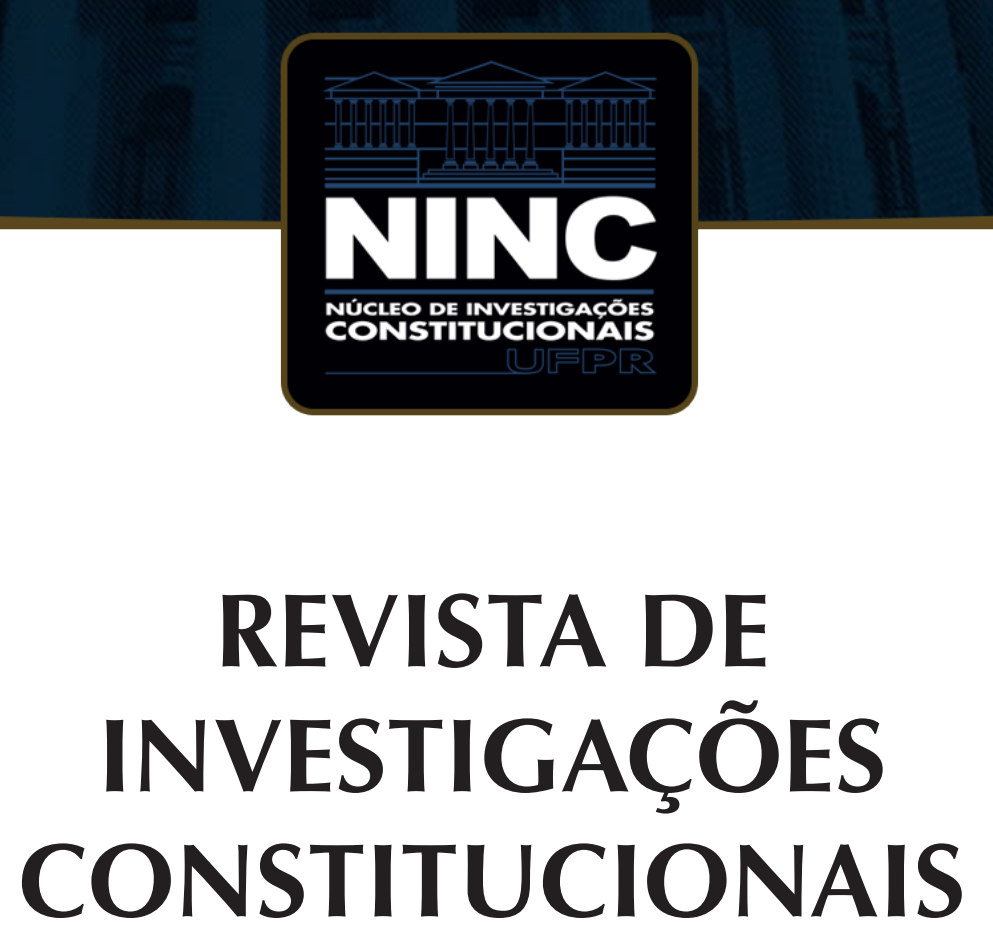

JOURNAL OF CONSTITUTIONAL RESEARCH

vol. 5 | n. 1 | janeiro/abril 2018 | ISSN 2359-5639 | Periodicidade quadrimestral Curitiba | Núcleo de Investigações Constitucionais da UFPR | www.ninc.com.br 


\title{
The principle of the dignity of human person: a reading of the effectiveness of citizenship and human rights through the challenges put forward by globalization*
}

\author{
O princípio da dignidade da pessoa humana: uma \\ leitura da efetividade da cidadania e direitos humanos \\ por meio dos desafios frente à globalização
}

\author{
ORIDES MEZZAROBA** \\ Universidade Federal de Santa Catarina (Brasil) \\ oridesmezza@gmail.com
}

\section{VLADMIR OLIVEIRA DA SILVEIRA***}

Universidade Federal do Mato Grosso do Sul (Brasil) Pontifícia Universidade Católica de São Paulo (Brasil) vladmiracademico@gmail.com

Recebido/Received: 24.07.2017 / July 24th, 2017 Aprovado/Approved: 31.12.2017 / December 31st, 2017

Abstract

Even today concepts that should have been overcome are debated, for example, the belonging of an individual to a State and, consequently, to its laws. The process of globalization, and the constant immigration resulted thereof, have led to profound changes in the relationship between the individual and the State, and especially, in the field of

\section{Resumo}

Ainda hoje se debate conceitos que deveriam ter sido superados, como, por exemplo, o pertencimento de um indivíduo a um Estado e, consequentemente, às suas leis. O processo de globalização, e a constante imigração daí decorrente, proporcionou profundas transformações nas relações entre o indivíduo e o Estado e, especialmente, na

Como citar esse artigo/How to cite this article: MEZZAROBA, Orides; SILVEIRA, Vladmir Oliveira da. The principle of the dignity of human person: A reading of the effectiveness of citizenship and human rights through the challenges put forward by globalization. Revista de Investigações Constitucionais, Curitiba, vol. 5, n. 1, p. 273-293, jan./abr. 2018. DOI: 10.5380/rinc.v5i1.54099.

*This article was translated from Portuguese to English by Cássio Eduardo Zen, LLM student at Universidade Federal de Santa Catarina - Brazil.

** Full Professor on the Undergraduate and Graduate Law Schools at Federal University of Santa Catarina (Florianópolis, SC, Brasil). Doctor of Law from the Federal University of Santa Catarina (Florianópolis, SC, Brasil). E-mail: oridesmezza@gmail.com.

*** Full Professor on the Undergraduate and Graduate Law Schools at the Federal Univerity of Mato Grosso do Sul (Campo Grande, MS, Brasil). Professor at the Pontifical Catholic University of São Paulo (São Paulo, SP, Brasil). Doctor of Law from the Pontifical Catholic University of São Paulo (São Paulo, SP, Brasil). Lawyer. Email: vladmir@aus.com.br. 
international human rights law. This means that the human needs began to be manifested regionally and internationally, in order to achieve the principle of the dignity of the human being. Thus, this article intends to investigate the link between citizenship and human rights, from new perspectives, through literature studies and deductive method, in order to answer the following questions: what are the added values to the concept of citizenship? And what is the current dimensions of citizenship?

Keywords: dignity of human person; effectiveness; citizenship; human rights; challenges of globalization. seara dos direitos internacional dos direitos humanos. Com isso, quer-se dizer que as necessidades humanas passaram a ser manifestadas regional e internacionalmente, com vistas à concretização do princípio da dignidade da pessoa humana. Assim, este artigo pretende investigar o elo entre a cidadania e os direitos humanos, a partir de novas perspectivas, por meio de estudo bibliográfico e método dedutivo, a fim de responder os seguintes questionamentos: quais os valores agregados ao conceito de cidadania? E qual a atual dimensão da cidadania?

Palavras-chave: dignidade da pessoa humana; efetividade; cidadania; direitos humanos/ desafios da globalização.

\section{CONTENTS}

1. Introduction; 2. Dignity of Human Being as basis for the human rights; 3. Citizenship in its different dimensions; 4. Human Rights and citizenship - convergences; 5. Globalization and new demands of citizenship (nationality, regionalism and universality); 6. Conclusion; 7. References.

\section{INTRODUCTION}

Liberal thought has laid the foundation for the emergence of the rule of law that, although it is continually shaped, stands on the pillars of the legal-dogmatic constructions around the world. Thus, we usually debate and deepen ourselves in some classic notions such as the belonging of individuals to a State and the law as a commandment targeting the general interest of a national community.

However, in present time we live the deep transformations from the process of globalization. One must observe that, just to point some of these changes, the human needs have manifested themselves in the global level, not anymore in the national grounds. This way, non State actors have emerged with great strength in the worldwide stage. And, in parallel with the national cultures, cosmopolite ones appeared. Also, the constant migrations are putting themselves against the ancient adoption of a nationality, the idea of remaining in a single country.

As an effect, State-Nation is challenged in its hegemony when having to conceive citizenship in its broader aspect, not only as a bond of political fidelity, as it was in its origin. This way, it is imagined a new form of State that incorporates the common values of all the subjects of a global community and promotes the defense of human rights with the support of the dignity of the human being.

Following this line of thought, this article attempts to discover some of the bonds between citizenship and human rights, having as premise the scope of human dignity, as since the ascension of human rights in modern juridical debates all over the world, having as consensus that the human dignity is the most important vector in the 
laws in force in States. With that, having as a starting point in this study the intrinsically connection between dignity and human rights, we will attempt to demonstrate that dignity is being put into reality as human rights become effective. On this sense, it is necessary to investigate its evolution in the juridical and philosophical thinking to demystify its contents and show how it became the main basis for human rights.

As basis for human rights, dignity also irradiates its effects in the contents of citizenship. It's with the development of human rights on the XX and XXI centuries, in the international field and timely incorporated in the internal field, we watch multiple rights conjugated with the dignity of the human being. At the same time, the content of citizenship had to be reviewed to include these new variables. This way, it is necessary to enquiry - which new values were added to the concept of citizenship? What is the present dimension of citizenship? To answer to all these questions, it is useful to think about the present concept of citizenship and its scope having as parameter for comparison the citizenship as it was molded in the Bourgeois Liberal State. This reflection goes through the analysis of the convergences between the concepts of citizenship and human rights, as both are shaped by their historicity and by the adding of values in the juridical world.

The analysis of citizenship in its dimensions is complemented by the cosmopolite vision of the present citizenship. On this rhythm, it is necessary to analyze the influence of the phenomenon of globalization on citizenship, adding the compelling paradigm of international cooperation and shared sovereignty between states in the interests of individuals. The global individual is in a cosmopolite international scene, frequently being put against new challenges, especially when having its citizenship weakened. From this a third and final question emerges to be put in the present work, that is, specifically about the way citizenship may be exercised, taking into account its widened dimensions in the globalized world.

This question is crucial given the various transformations undergone by the state in the twentieth century, and its effects on the twenty-first century, particularly with the development of international law of human rights, emergence of the UN and other international regional organizations. The focus on the exercise of citizenship in the global world is essential to understand the process of citizenship and its effectiveness in all its aspects, that in a complementary way - or the principle of complementarity - encompasses the three systems of protection of human rights currently enforced.

\section{DIGNITY OF HUMAN BEING AS BASIS FOR THE HUMAN RIGHTS}

The discussion between philosophers on the subject of dignity is rather ancient in the West, fruit of a jewish-christian tradition and belief of man as image of God. ${ }^{1}$ With

1 Comparato (COMPARATO, Fabio Konder. Ética, direito, moral e religião no mundo moderno. São Paulo: Companhia das 
the Christian thought, the notion of personal individual dignity was developed. It's on St. Thomas Aquinas² works, that lesson that "dignity is inherent to man, as species" is found.

The development of the jusnaturalist doctrine contributed effectively to the subject of dignity. The movement had as leading scholar Kant ${ }^{3}$, who excelled himself for identifying in society two categories - price and dignity. According to Kant, 4 the price would be an external value, of particular interest in the market. As for dignity, it would be an internal moral value, dignity would not find equivalent, it would not be possible to replace it as it would be done with a product. From this observation Kant's quote comes regarding man as the end, not the mean to reach any end. On Kant's notorious quote"man, and in general all rational being, exists as an end in itself, not just as a mean to any use of this or that will".

Following the same lines, Comparato states that dignity must be treated as na end in itself, not as a mean, and adds that it results from the fact that that the person lives in conditions of autonomy, being able to guide itself by the laws it creates itself. 5 On the same lines, we cannot forget to mention the proposition from Sarlet towards a juridical concept of human being dignity. According to the scholar, we may define the dignity of human beings as:

[...] the intrinsic and distinctive quality of each human being that makes it worth the same respect and consideration by the State and community, implying, therefore, a complex of fundamental rights and duties which assure the being against each and any act of degrading and inhuman content, as well as guarantee the minimal conditions of living to a healthy life, and also providing and promoting its active and co-responsible participation on the destinies of its own existence and live in community with the other human beings. ${ }^{6}$

\footnotetext{
Letras, 2006. p. 479) explains how the concept of person was elaborated in christianity as substance, as purpose of the image of Jesus Christ, in its double condition as man and Son of God.

2 As. Summa Theologiae.

3 It is Worth mentioning the reflections from Bittar (BITTAR, Eduardo C. B. Hermenêutica e Constituição: a dignidade da pessoa humana como legado à pós-modernidade. In: ALMEIDA FILHO, Agassiz; MELGARÉ, Plínio (Orgs.). Dignidade da Pessoa Humana - fundamentos e critérios interpretativos. São Paulo: Malheiros Editores, 2010. p. 247) about Kant's thesis. According to him: "In fact, dignity has to do with this capacity to be autonomous, as the moral and legislative ration acts. If there is in the world of absolute ends (field of unconditional, non-achievable, inappreciable), in counterpart to the world of relative ends (field of price, exchange, useful and variable), the human definition derives from its invariable and inalienable condition, since no one is more valuable than anyone, no one may receive more value than anyone, different from things in comercio.

4 KANT, Immanuel. Fundamentos da metafísica dos costumes. São Paulo: Ediouro, 2000. p. 120.

5 COMPARATO, Fabio Konder. A afirmação histórica dos direitos humanos. São Paulo: Saraiva, 1999. p. 20.

6 SARLET, Ingo Wolfgang. Dignidade da pessoa humana e direitos fundamentais. Porto Alegre: Livraria do Advogado, 2001. p. 60.
} 
We can also address the double vision from Bittar on dignity. For him, "dignity is about what one grants to the other (experience from the outside), as well as to itself (experience from the inside)".7 Thus, the dignity that comes from the outside is the one shaped by the instruments, generally speaking, offered so that the person may have a worthy life. Meanwhile, the dignity that comes from the inside is the "personal dignity", that grows with the self-appreciation. Such notions are undeniably interconnected, according to Bittar "one tends to dignify (experience from the outside) who more and better dignifies itself (experience from the inside)". Notwithstanding this observation, it is important to underline that each individual is a legitimate agent to seek its dignity against the State or other subject, dignity from the outside, simply for being a human person.

However, with the evolution of the rules protecting human rights, it is observed that the connection between dignity and human rights, namely the vision that dignity comes with rights, just took place with the advent of major international texts and constitutions after the Second World War.

The juridical reappearance of dignity in the post-war showed a historical reaction against the totalitarian regimen that violated dignity itself on a planned basis when trying to carry out a project to define the "human being" by its predicates. Regarding that Barzotto explains that: "[...] the Nazi defined the human by the predicate 'race', and the communist by the predicate 'class'. Human being is an issue to be studied in scientific terms. Therefore the Nazi scientism, that assigned to biology the task of funding anthropology, and of communism, that assigned the task to history". In this perspective, the objective was to frame the human being - regarded as a problem - into a definition. If it was not fit into the frame, its destiny was to be eliminated.

This conception of exclusion of the human being ${ }^{9}$ which lasted during the Nazi domination was a fertile ground for the ascension of dignity as a fundamental value of the person. This way, the bad experiences from the Second World War marked a new historical moment of reorienting international politics in favor of human rights. Thus, the notion of International Law of Human Rights was formed based in the Nuremberg Tribunal, the creation of the UN and the presentation of the Universal Declaration of Human Rights.

We may have as a premise that human rights are aimed at satisfying individual human needs. These can be demanded by socially mobilized groups that express

\footnotetext{
7 BITTAR, Eduardo C. B. O direito na pós-modernidade e reflexões frankfurtianas. 2. ed., Rio de Janeiro: Forense Universitária, 2009. p. 301.

8 BARZOTTO, Luiz Fernando. Pessoa e reconhecimento - uma análise estrutural. In: ALMEIDA FILHO, Agassiz; MELGARÉ, Plínio (Orgs.). Dignidade da Pessoa Humana - fundamentos e critérios interpretativos. São Paulo: Malheiros Editores, 2010. p. 55.

9 Lafer explains (LAFER, Celso. A reconstrução dos direitos humanos: um diálogo com o pensamento de Hannah Arendt. São Paulo: Companhia das Letras, 1988. p. 117) that on the logic of totalitarianism "everything is possible" and the human being was deemed superfluous. There was no minimal consideration for the individual's intrinsic value.
} 
common needs in order to recognize such rights ${ }^{10}$. It is on this sense, as when we transpose the binomial notion of necessity/right to the process of drawing up legal rules, we find that these standards when they set certain limits to human freedom by imposing behaviors denote the social compliance through an intrinsic process of natural accommodation.

Following the same lines Silveira11 clears up that

[...] rights are born and modified obeying a core formed by the axiological feeling of a society, which from a given fact adheres itself to a certain value, which, by its turn, becomes to be normatized internationally as well as nationally by States, with imperative basis in the idea of human being dignity.

Therefore, in view of the development, the right must always be remaking itself in the face of social mobility. It is an adaptation process, considering the new values incorporated into the social environment, whereby the right must renew itself, always shaping up to such expectations.

Drawing a parallel with the study the elements composing human rights we can relate what was said with the aspect of its history, which shows the evolutionary chain of the rights to its time. Therefore, in congruence with the explanations from Silveira and Contipelli12, it is important to note that the historical evolution of human rights takes place through a process that is called "dinamogenesis", which represents a process through which the social community in a certain moment recognizes as valuable something that founds the human right. According to the scholar "this value brings a new grading to the dignity of human being, that supposes a new orientation and a new content, as consequence of its connection with the present parameter".

The dignity of the human person will be made concrete by the preponderant value in a given historical time, for example, freedom, equality and solidarity. Thus, on the Universal Declaration of Human Rights of 1948, an important instrument of universal human rights and main spreader of values over the world, the human being dignity took the place of pillar to all the rights in it enshrined. In the preamble, dignity was crowned as basis to all human rights, since it was recognized to all members of the human family and its equal and inalienable rights. In the first article, it is stated that all

\footnotetext{
10 In this sense, Nader (NADER, Paulo. Introdução ao estudo do direito. 24. ed., Rio de Janeiro: Forense, 2004. p. 17) states that: "even if it possesses a permanent axiological substrate that reflects the stability of the 'human nature', law is an engine subject to the society and should have its direction in according to social ends".

11 SILVEIRA, V. O. Speech given at Faculdades Metropolitanas Unidas - FMU, on the August 13th 2008, during the law week that happened from 11 to 15 August 2008.

12 SILVEIRA, V. O.; CONTIPELLI, E. Direitos Humanos Econômicos na perspectiva da Solidariedade: desenvolvimento integral. In: XVI Encontro Nacional CONPEDI, 2008, Salvador - BA. Anais XVI Encontro Nacional do CONPEDI, 2008.
} 
human beings, since they have reason and conscience, are born equally free in dignity and rights. ${ }^{13}$

From the standpoint of domestic orders, human dignity appears today in several constitutional texts. The Weimar Constitution in Article 151 already proclaimed that "the ordering of economic life must match the principles of justice in order to guarantee everyone a decent existence." And in Brazil, we can say that it is at the epicenter of the legal system, as the constituent of 1988 elevated it to the rank of fundamental principle of the Republic, structural pillar of the State organization, as provided in Article 1, paragraph III of the 1988 Constitution of Federative Republic of Brazil. This principle irradiates to all other sections of the Constitution, for instance Article 170, caput.

Thus, we can infer that the dignity as a criterion of integration of constitutional order in force is suitable to be the grounds of human rights, as it were incorporated into the domestic constitutional system forming the current list of fundamental rights. In another way, there is no doubt that the nature of dignity as the foundation of human rights (or fundamental rights from the point of view of contemporary constitutions) ${ }^{14}$ makes it to irradiate its effects all over the juridical order (intern and/or international), implying the recognition and protection of rights in all of its dimensions.

\section{CITIZENSHIP IN ITS DIFFERENT DIMENSIONS}

A careful reading of history or the course of human rights leads us to reflect together on the concepts of human dignity and citizenship, to the extent that they emerge from the need 15 to protect the human person in its various dimensions. Given that the human dignity was revisited in the previous chapter, we now examine the various conceptions of citizenship in order to identify points of convergence with human rights.

In the period of absolute State in the sixteenth century, our idea of citizenship was manifested in the relationship between sovereign and subject. Citizenship was part of the absolute state, to the extent that the citizen was inside a sphere in which it held its own legal rights in relation to their sovereign. It should be noted, however, that slaves and foreigners were not considered citizens, nor women and children, as they were subordinated to the head of the family. Thus, the citizen of that time, in the

\footnotetext{
13 This important historical document was later developed by the international Covenants related to Civil and Political Rights and Economic, Social and Cultural Rights of 1966.

14 It is important to notice that one should not mistake human rights and fundamental rights, because even if they are related, they are different categories. Human rights (recognized internationally) inherent to the person should be recognized as well by the positive law of States. As the recognition is produced, they become fundamental rights, meaning, according to Pérez-Luño "a sector of utmost importance in the juridical order of democratic countries" (PÉREZ LUÑO, A. E. Derechos humanos, Estado de derecho y Constituición. 8. ed. Madrid: Tecnos, 2003. p. 30).

15 These demands appear every time when situations of uncertainty are faced, as the ones that presents us progress and crisis, for instance.
} 
concept expressed by Bodin was a free subject, for he had rights in the face of the sovereignty of another. 16 Moreover, the criterion for the characterization of natural born citizen was the ius sanguinis (nationality) - citizen was the son of a free citizen.

Hobbes enriched the concept of citizenship, and individualized it and relating it to the moment when the subject, in his state of nature, seeking peace in the face of "perpetual war", voluntarily submits to the sovereign. For Hobbes, this state of submission when the individual recognizes itself as a citizen, limiting its will and receiving in exchange the protection from the State. 17

From the seventeenth century, with the struggle against the absolute State by the Enlightenment, the freedom of the individual towards the sovereign was advocated. On this debate, citizenship was turned to the formation of the political community and the participation of society in such community. In fact, the transformation on the concept of citizenship happened with the change of the nature of the contract that gave origin to the State. In Hobbes, the Social Contract was based in the submission of the subjects to the sovereign, while in Rousseau, with enlightened ideas, there was a consensus between free and equal individuals that took the form of a State. ${ }^{18}$

With the strength of the bourgeois revolutions (English - in the end of the seventeenth century; American and French - already in the eighteenth century), we witnessed a profound change in the conception of citizenship, given the very historical context of the transition from commercial to industrial capitalism that gave rise to economic domination of the bourgeois class. It is important to emphasize that the Declaration of the Rights of Man and Citizen (August 26, 1798) gave political-juridical connotation to the "liberal citizenship", when stating that all individuals are born free and equal in rights and remain therefore in what relates to freedom, propriety, security and resistance to oppression. About the French Revolution and the concept of citizenship, on the eighteenth century, Dallari teaches us that:

This movement was very important because it influenced mosto f the world to adopt the new model of society, created as consequence of the Revolution. In this moment and this environment that the modern conception of citizenship was born to proclaim the elimination of privileges, but which, shortly after, was used to assure the superiority of the new privileged. ${ }^{19}$

\footnotetext{
16 BODIN, Jean. Lex Six Livres de La Republique. Paris: Librairie Générale Française, 1993. p. 139.

17 HOBBES, Thomas. Do cidadão. São Paulo: Martins Fontes, 2002. p. 32-34.

18 ROUSSEAU, Jean-Jacques. O Contrato Social. Rio de Janeiro: Ediouro, 1992. p. 35.

19 DALLARI, Dalmo de Abreu. Direitos humanos e Cidadania. 2. ed., São Paulo: Moderna, 2004. p. 19.
} 
Citizenship in the factual Liberal State went into crisis, even though it served to the recognition of rights, it was permanently denied, on the political point of view, to the poor, the women and the illiterate as the voting by census was implemented. It's also possible to mention the coexistence with the slavery system for a large period. In the nineteenth century, citizenship was granted by the State as a status to its members, who by their turn now had benefits/political rights, for instance to vote and to be voted.

But, on the other hand, at that time, social values were not taken into account. It was a deeply individualistic model criticized by Marx, considering the consequent disparity in the distribution of property, needed to be surpassed by conceiving rights not to the isolated individual being, but to the individual considered fellow citizen. 20 In the Marxist view all individuals are citizens and vice versa, so all should be seen as equal and belong to the same political community.

In the twentieth century we were faced with a new concept of citizenship. Marshall, 21 concerned with the evolution of citizenship in England, proclaimed his articulating elements that would be civil (eighteenth century), political (nineteenth century) and social (twentieth century) rights, conquered in this order. In this sense, the interpretation of Marshall approached considerably the idea of gradual expansion of rights by the needs. Indeed, after World War I, when we refer to the rights of human beings, we are not speaking of individual rights only, whether civil or political rights but we also include social, economic and cultural rights. In this rhythm the liberal concept of citizenship was finally surpassed, so it would be understood as an ensemble of civil, political and social rights. In other words, citizenship was not only regarded in terms of individuality, but widened by the needs of the person while developing itself fully inside a collectivity.

At present, new variables are being added to the process of citizenship, making it essential to return to think about its foundation, ownership and content. We have as starting point the exhaustion of the liberal conception of citizenship and the new challenges of the twentieth century, be them social (poverty, exclusion and immigration), economic (globalization), or cultural (pluralism and diversity). On the other hand, we see enshrined values that are chained as an indivisible set of human rights which encompass the civil and political rights, whose owners are individuals, the social, economic and cultural rights, whose owners are the collectivity, and now the rights of solidarity, whose ownership is of mankind on a diffuse and universal perspective22. Therefore, the present dimension of citizenship must be regarded as horizontal23, with

\footnotetext{
20 MARX, Karl. Para a questão judaica. São Paulo: Expressão Popular, 2009.

21 MARSHALL, T. H. Cidadania, classe social e status. Rio de Janeiro: Zahar, 1967.

22 Check for more: PÉREZ LUÑO, A. E. La tercera generación de derechos humanos. Navarra: Thomson-Aranzadi, $2006 . p .232$.

23 No longer vertical, as it was in the relationship between subjects and the sovereign State.
} 
the involvement of fellow citizens equally regarding the access to all these rights and the fulfillment of their duties, implying a relationship of intersubjectivity and solidarity.

\section{HUMAN RIGHTS AND CITIZENSHIP - CONVERGENCES}

Not always the concept of human rights and citizenship have walked together. It should be noted that only the late Middle Ages, since the overcoming the absolutism and the advent of the rule of law, after fights established for this purpose, the concept of citizenship is linked to the development of human rights.

Traditionally, from the modern state, citizenship has a political bias, identified in a context of individual participation in shaping the will of society and its government. While human rights, as we have observed, had their origin and foundation on the jusnaturalist thought, with emphasis on human dignity, which has resulted in a list of rights inherent to the human being. These must be protected from violations of all kind, for the simple fact that the individual exists as a human person. One should note that these concepts appeared with their own connotations, stressing that in the original thought the human rights were inherent to human beings independent of the will from the political society.

Through a series of historical and cultural changes, these concepts, at first independent, started to be analyzed together, converging on a single stem of ideas guided by the premise that people should have rights essential to their life with dignity, and that it would also be increasingly important the expansion of these rights. It was therefore on the basis of on human dignity, that there was a strong approximation between the discourse of human rights and citizenship.

The French Revolution was an important milestone, in which there was a noticeable expansion in the conception of citizenship to cover the basic rights of man. The proclamation in the French National Assembly in 1789, of the Declaration of the Rights of Man and Citizen, with universalizing pretensions, defined the modern citizenship, stating that every man has rights inherent to his nature, which are exercised in the context of citizenship.

About this document and its pretention of universality, it is important the lesson by Torres, because - "Man was regarded in the universal sense, but abstract, since there was no juridical classification of rights on the international field, which depended on a universal contract".24 However, we have observed over the course of the following centuries an historical process of widening of human rights being written in several documents on the international field, conquering regional and worldwide spaces.

24 TORRES, Ricardo Lobo. A cidadania multidimensional na era dos direitos. In: TORRES, Ricardo Lobo. Teoria dos direitos fundamentais. Rio de Janeiro: Renovar, 2006. p. 246. 
It is worth remembering that the rights of the first dimension take care of the preservation of the public liberties, protecting life, freedom, propriety and others, as to limit the power of the State 25 . The rights of freedom gave the initial content of citizenship on the context of liberalism. Schäfer explains that "the first conceptions of rights had as objective the protection of the citizen towards the absolute State (Leviathan, in Hobbes's classical conception), as freedom is a prerequisite for the exercise of other constitutional powers." 26

It is important to stress the existence of the space of "political freedom", that may be exercised to choose the destinies of the Country through representations or directly. The concept of citizenship, in that moment, was bonded to the right of freedom of movement and the political demonstration, in clear clash with the predominant will of the feudal lords, the noble and the clerics. We may say that the fall of the Ancient Regime 27 and the following ascension of the liberal State were historical facts that marked the rising of the modern concept of citizenship.

On the social and economic conception, the role of the State is that of the satisfier of rights, that demand it positive actions with objectives of equality, which means, interventionist measures in favor of people facing problems in the development of their personality. ${ }^{28}$. Therefore, State had from now on the obligation of fulfilling rights and guarantee, for instance, job, fair payment, education, health, aiming minimal conditions of living for the citizen. This way, the "minimum standard of existence" integrated the concept of citizenship, therefore, there is a right to minimal conditions of living and dignity that cannot escape from the State's intervention to become reality.

The struggle for individual freedom was a parameter for the development of the rights of first dimension and the need of equality in the the distribution among men was the basis for the rights of second dimension. On this historical moment, we cannot forget that beyond these, the rights of solidarity emerged, rights of third dimension, fruit of a mutual relationship between people or groups with common needs, as the environment, the peace among people, the development of States among others. The idea of solidarity has special relevance to the fulfillment of fundamental obligations,

25 On this direction Bastos teaches (BASTOS, Celso. Curso de Direito Constitucional. 22. ed., São Paulo: Editora Saraiva, 2001. p. 223) that: "[...] the definition of individual rights and guarantees is made of the limits to the power of the State, in the inhibition of its activity, in the creation of a public power incompetence zone of action. This region is translated in an area of juridical protection of the individual, inside which the State cannot enter, under the penalty of unconstitutionality".

26 SCHAFER, Jairo. Classificação dos direitos fundamentais - do sistema geracional ao sistema unitário. Porto Alegre: Livraria do Advogado. 2005. p. 19.

27 It is Worth mentioning that the Declaration of Rights of the Man and Citizen, that bought a definition of citizenship that is still used in present times, stresses the rights of the citizen as those political and civil ones.

28 The Historical perspective of Human Rights of second dimension is presented by Araújo and Nunes (ARAÚJO, Luiz Alberto David; NUNES, Vidal Serrano. Curso de Direito Constitucional. 9. ed., São Paulo: Editora Saraiva, 2005. p. 115-116), the following way: "If fundamental rights of first generation had as focus the freedom against state discretion, the second generation ones start from a more evolved place: men, free from the oppression of Public Power, claims now a new form of protection of his dignity, meaning the satisfaction of the minimum necessary to have dignity". 
since citizenship implicates a subjective relationship that encompasses rights and duties of men.

Sousa Santos advocates the combination of individual and collective forms of citizenship, indicating the widening of the concept of citizenship beyond the idea of reciprocity and equivalence of rights and duties. ${ }^{29}$ Following these lines, we express the idea of solidarity as tendency to call us upon defending it collectively what is common to us all, as it is with the environment and development.

Considering the connection between citizenship and human rights, we believe that the concept of citizenship encompasses civil, political, social, economic and difuse rights, which incorporate, express and bond themselves to the values of freedom, justice, equality and solidarity. This position is consonant to the thoughts of Arendt 30 and Laffer who sees citizenship as the conscience of the individual as the right to have rights

Citizenship is a right to have rights, because equality in dignity in human rights is not a grant. It is built on the collective life, which requires the access to the public space. It is this access that allows for the construction of a common world through the process of assertion of human rights. 31

Continuing, one can also extract that citizenship became all those rights granted to the citizen, not only because the dignity demands the fulfillment of these rights, but also the contrary, since it is itself condition to the exercise of citizenship.

Cunha stresses that citizenship has new challenges and these cannot be defeated with the "law with its eyes closed". It is necessary an approach as wide as possible, which encompasses a "law with wide open eyes to the reality and the social problems".32 For that, we keep stressing that human rights in their dimensions incorporate essential rights inside the society. That means, they create opportunities for the development of citizenship, an contribute as well to its effectiveness.

\section{GLOBALIZATION AND NEW DEMANDS OF CITIZENSHIP (NATIO- NALITY, REGIONALISM AND UNIVERSALITY)}

Globalization bonded every time more the peoples on an interdependence relationship. The domination (imperialism) imposed on political-ideological terms facing

\footnotetext{
29 SOUSA SANTOS, Boaventura de. Pela mão de Alice. O social e o político na pós-modernidade. São Paulo: Cortez, 2006. p. 276. 30 ARENDT, Hannah. The origins of totalitarianism. Nova York: Harcourt Brace Jovanovitch, 1993. p. 299-302.

31 LAFER, Celso. A reconstrução dos direitos humanos: um diálogo com o pensamento de Hannah Arendt. São Paulo: Companhia das Letras, 1988. p. 146-166.

32 CUNHA, Paulo Ferreira. Constituição Viva: cidadania e direitos humanos. Porto Alegre: Livraria do Advogado, 2007. p. 61.
} 
the clash between West-East collapsed with the Berlin Wall. However, economic domination took place, while tanks were no longer needed in the streets, but its efficiency is great. Thus, the relationships between North-South, or rich/poor countries becomes more relevant, since the value of democracy - so dear - may be menaced due to the shift of centers of decisive power inside States. One may say that, if the globalization indeed brought together States and people, it didn't foresee how to realize this process without aggravating the relations of domination

Therefore, Bonavides 33 warns for a species of globalization that destroys the sovereignty of the State, denying it its essential quality of supreme power, ignoring the ethical, factual and axiological elements that form the basis of national interests of the juridical order. With this species, the basis of the system, the democratic structures of power and the constitutional basis of the State organization are menaced.

It is well known that the rivalries in times of imperialism, that took place between hegemonic countries and caused the two biggest wars in the world, were disappearing, causing a relationship of interdependence between powers, to the level of cooperation and regional integration.

However, under the effects of a "political globalization" in the concept of Nation -State, Sousa Santos exposes certain tendencies already listed by Bob Jessop, especially in relation to the transformation of State's power. He describes it this way:

First of all, the denationalization of the State, a certain voidance of the national State apparatus that occurs because of the fact that the ancient and new capacities of the State are being organized, as territorially as functionally, to the subnational and supranational levels. In second place, the de-statism of the political regimes reflected in the transition of the concept of government to governance, that means, from a model of social and economic regulation founded in the central role of the State to another based in partnerships and other forms of association between governmental, para-governmental and non-governmental organizations, upon which the State has duties of coordination only, as primus inter partes. And, finally, a tendency towards the internationalization of the National State, expressed in the increasing strategic impact of the international context in States' actions, that may include the widening of the fields of

\footnotetext{
33 According to Bonavides (BONAVIDES, Paulo. Revista do Instituto dos Advogados Brasileiros, Rio de Janeiro, ano XXXIV, n. 92, abr./jun. 2000.): "The globalization neoliberals only combine five verbs on their language. They intend to undertake, as soon as possible, the extinction of national sovereignty, both internal and external. The five verbs are de-nationalize, de-statize, de-constitutionalize, de-regionalize and disarm. By the simultaneous work of these contumacious actions, impertinent and disruptive, the country faces its worst crisis in History. This way, soon on the people's conscience, in the courts, in the forums, in the citizenship's memory, the memory of the lost and sacrificed freedom will vanish, not having a place to deal with the elements constitutive to the identity, the Nation, the State, the Constitution, the Region and the Armed Forces".
} 
action of the National State every time that it would be necessary to fit the internal conditions to the extra-territorial or transnational demands. 34

With concerning the reduction of the power of the nation-state, Vieira asserts that "the nation states are weakened as they can no longer control the dynamics that go beyond its territorial boundaries" and that "the global interdependence of several processes ends up reducing in fact their power of decision, even if by law they continue lords of their space of jurisdiction. 35 Indeed, decisions within the state exist autonomously, but cannot be detached from the external environment contingencies, ie, cannot be decontextualized from the international scene.

In a context of globalization in which borders are weakened due to the large and fast access to information, it is essential that the sovereign States come, at the same speed, to adjust to the new global society that is increasingly consolidated. The rights emerging from the terrifying context of the Second War and the hope represented by the founding of the UN inaugurated a perspective of international cooperation in which the nation state is surpassed by a new conception of the state, which Häberle calls "Cooperative Constitutional State." 36 In it, the consolidation of this new paradigm for the state generates expectations of increased citizenship in the domestic and international plans, especially with regard to their legal effect. At this pace "governmental solidarity of cooperation" or "cooperation beyond borders", in which mutual assistance between states is seen as co-responsibility is a core part of the "Cooperative Constitutional State", along with the universal rules human rights.

Given this new reality, it is already observed increased international cooperation - and, consequently, it is required reformulate the concept of sovereignty, since the states are not self-sufficient, ie, no longer operate individually in international relations, but interdependently. Similarly, Bittar adds the "disappearance of a immutable design of sovereignty," as one of the transformations of post-modernism that embraces the transition from a national state to the post-national state. In his words, about the end of the old conception of sovereignty:

[...] As a role model with absolute capacity of self-determination of the state (to create rules, execute rules and judge according to rules, regardless of the intervention of external forces), either by the inability of states to isolate themselves from international economic policies (IMF, IBRD), or by the deep and abiding interference of globalization

\footnotetext{
34 SOUSA SANTOS, Boaventura de (Org.) A globalização e as ciências sociais. 3. ed., São Paulo: Cortez, 2005. p. $37-38$.

35 VIEIRA, Liszt. Cidadania e Globalização. 8. ed. Rio de Janeiro: Record, 2005. p. 105.

36 HÄBERLE, Peter. Estado constitucional cooperativo. Trad. Marcos Maliska e Lisete Antoniuk. Porto Alegre: Livraria do Advogado, 2007.
} 
on domestic political scene of the States, or by breaking the concept of sovereignty-isolation-competition-protection-nacioanalism towards an integration-cooperation exchange concept, either by the sufficient number of international mechanisms, including and especially related to human rights, which provide tools for the action of international forces to quell attacks on human rights even when they occur within a nation state (Rwanda, Kosovo, Afghanistan, Iraq ...). 37

Currently, the international community tries to find solutions that reconcile the old concept of sovereignty with the needs for cooperation and integration among states, given that the states, even though they are strong and powerful, cannot resolve current issues such as terrorism, environment, capital flows and crimes against humanity, among others, by themselves.

It is essential to clarify that, in shared sovereignty, states do not renounce their sovereignty, but exercise it in a way shared with other states and those matters specifically provided for in treaties. This apparent limitation of the state, characteristic of shared sovereignty, guarantees the solidarity and democracy, and a minimum basis of rights arising from the principle of complementarity which should always be exercised in favor of human beings. One can then say that there is no loss of sovereignty, because insofar as sovereignty is shared, State would have jurisdiction outside their territories as well, in universal themes shared with other states. In other words, sharing implies losses and gains in a new perspective.

It is important to highlight that sovereignty is not something that has a greater or lesser extent - if it is state it's sovereign. Sovereignty is a condition of the state and not a quality that exists in greater or lesser degree. Thus, what is proposed in the Constitutional Cooperative State is just the opening of the State for a legal and ethical dialogue with the international community and the consequent sharing of sovereignty rather than against a political-ideological relation or economic and technical domination.

Note that this new concept holds that, in its current stage of development, the Constitutional State is not justified by itself, but is conditioned by external circumstances - in other words, it's conditioned from outside. It is no accident that our Magna Carta contemplates themes of the constitutional dualism (Article 4) and the promotion of human rights (Article 5, paragraph 2), as it happens in the constitutions of many countries and especially in documents from the Communities

In this rhythm, it is no longer possible to think of citizenship without contextualizing in the globalized world and the paradigm of the Constitutional Cooperative State.

37 BITTAR, Eduardo C. B. 0 direito na pós-modernidade e reflexões frankfurtianas. 2. ed., Rio de Janeiro: Forense Universitária, 2009. p. 348. 
In other words, the citizen should be considered as part of a cosmopolitan international scene, whose universally valid value is human dignity.

The present citizenship finds itself connected to a humanist project of universalist and cosmopolite conception, where the true "status mundialis hominis" 38 is achieved. Accordingly, the traditional and reductionist vision that equates citizenship with the relation of belonging to a state is overcame. On the other hand, from the recognition of the phenomena of "supra-statehood" citizenship is no longer considered under the unilateral aspect - as the individual's unique bond with his state - being admitted in the multiple formas diversity of citizenship or multilateral citizenship.

We witnessed intergovernmental efforts to tackle the challenges posed by globalization. In this sense, appeared as the most visible integrated regional markets, such as the European Union, NAFTA and Mercosur. In the example of the European Union we saw the overcoming of the simple step of building a common market to include laws and supranational institutions. This reflected in the concept of citizenship, because we now have "European citizens", according to Maastricht 39 . About that, Alves 40 explains that this new citizenship occurs in the opposite way to the one from Marshall: "from the economic rights to the social and then to the civil, to reach, maybe, in the future, the political citizenship, without crushing nationalities".

It is Always good to remember, as states Bobbio, the most important task of our time, regarding human rights, is not to give them basis them, but to protect them. ${ }^{41}$ The relentless effort of reasoning very made it difficult its protection, considering the various theoretical concepts, from several religious, political and ideological sources. Surpassed this issue, we move towards a consensus that universalizes such rights, when we expand in a complementary and integrative form the systems of protection: (1) Domestic-national, (2) international-regional, and (3) international-universal. Thus,

\footnotetext{
38 Read on these lines, HÄBERLE, Peter. Derecho Constitucional Común Europeo. Tradução de E. Mikunda. In: PÉREZ LUÑO, Antonio Enrique (Coord.). Derechos humanos y constitucionalismo ante el Tercer Milenio. Madrid: Marcial Pons, 1996.p. 187-224; PÉREZ LUÑO, A. E. La universidad de los derechos y el Estado constitucional. Bogotá: Universidade Externado de Colombia, 2002.

39 It became known as the Treaty of European Union and was signed on February 7th 1992. One of its innovations was the institution of the European citizenship next to the national citizenship, granting rights to Europeans to circulate and reside freely in the community, to vote and to be elected on the State where they reside, to have diplomatic and consular protection and right to petition before the European Parliament and the presentation of complaint before the European Ombudsman.

40 About the Mercosur, the author clears that this process is still starting when comparing with the European Union, because it doesn't "foresee, at the moment, nothing similar, but it's worth as a consultation organ surpassing the economic sphere" (LINDGREN ALVES, José Augusto. Cidadania, Direitos Humanos e globalização. In: PIOVESAN, Flavia (org.). Direitos Humanos, globalização econômica e integração regional: desafios do direito constitucional internacional. São Paulo: Max Limonad, 2002. p. 91).

41 BOBBIO, Norberto. A era dos direitos. Tradução de Carlos Nelson Coutinho. Rio de Janeiro: Campus, 1992. p. 25.
} 
in the national citizenship we have the figure of the State protecting its nationals (eg, Brazilians) with fulcrum on written fundamental constitutional rights. In the context of regional citizenship, the guarantee shall be given by organs from regionalized systems, such as the OAS, AU and EU in the protection of American, African or European, respectively, based on regional human rights. In the universal context, the protection is directed to human beings, as a citizen before the UN42, under the aegis of universal human rights.

This broad and complementary view of the systems of protection of human rights is consistent with the development and fulfillment of citizenship, given its multilateral design. Thus, we are moving forward in the protection of human beings satisfying their claims under the umbrella of a common denominator that allows it to be a citizen of the world. This paradigm of citizenship is with which the individual holds multiple citizenships and has been able to exercise them in their political community or at international level, always according with the cosmopolitan and humanist project acclaimed by the instruments of human rights protection.

\section{CONCLUSION}

1. On a brief reflective effort it is not difficult to observe that together with the crushing globalization, produced by the capitalist mode of production, there is a huge movement in course over some centuries until now, to widen the rights, based in the human conviction that all are equal in dignity. In great works with thesis that inspired the conscience of the present individual we may notice Locke (Seventeenth century) advocating a founding pact and attributing individual and inalienable rights to all men; Rousseau (Eighteenth century) advocating that sovereignty belongs to the people, that by its turn should exercise it directly and stating as well that equality propels freedom and not vice versa; Kant stating that the human being is distinct from things, because it has dignity, makes this thought echo in the Universal Declaration of Human Rights (1948).

2. This way, the human being dignity reemerges as criterion of integration of the International Law of Human Rights and the constitutional order in force in countries, becoming the main element of support of human rights and the fundamental rights - as prescribed in the internal law - irradiating its effects all over the juridical order, including to citizenship, as both dignity and citizenship are concepts attached to the need to protect the human being in all of its dimensions.

3. The present citizenship has a dynamic meaning and should be regarded in its widest dimensions, being connected with the constant evolution of human rights.

42 We must stress the First Optional Protocol of Civil and Political Rights, that attributes to the Human Rights Committee the power to receive petitions from individuals against the State. 
Citizen and Human Rights, both, form an historical concept, which makes its senses to modify and in space and time, following the progress of mankind.

4. With the specific case of citizenship, that happens not only because of the rules (of nationality) that defines who has and ho doesn't have citizenship (ius sanguinis, ius solis), but because of the distinct rights and duties that mark the citizen on each State and before the international community. On this speed, we face a citizenship that encompasses the civil, political, social, economic and diffuse rights and are attached to the values of freedom, equality, justice and solidarity.

5. We note that, even inside each State, the concept and the practice of citizenship is being widened considerably over the last century. The fast pace of such changes, especially because of the technological and cultural advances, turns what could be considered in a certain moment a dangerous subversion of the order something usual, "natural" in a following. Today, there is no Western democracy where women have no right to vote - which was considerable unthinkable short while ago, even in countries as developed as Switzerland. It is worth remembering that the basic right to voting had been linked to ownership of proprieties, to the entitlement on public service or functions or even the fact of belonging or not to a certain kinship.

6. As for the role of the globalized State, we may see that due to the present meaning of citizenship, there is to the State the need of cooperation, based on the will to act together in the international field, in regional and global levels. In the context of the international cooperation to defend human rights it is possible to observe the shared sovereignty and the Constitutional Cooperative State that adds to its structure elements of opening cooperation and integration that de-characterize the Nation-State as a closed structure focused on national sovereignty. This way, the international community gets the conditions to set minimum standards of the human being's protection - which will guarantee them even in periods of institutional instability of States, and also favor the essential advancements of human rights in places where the power of governs (and dominating powers) have not yet been limited. Sovereignty cannot, therefore, be evoked as shield to protect violations of human rights though the invocation of the domestic jurisdiction clause, but as instrument to enforce the protection of individuals and peoples.

7. This way, the principle of shared sovereignty must be in tune with the necessary international cooperation in the field of human rights, echoing to the real needs of mankind, through the relation of complementarity between the spheres of protection that base the distinctive complementary citizenships. Thus, when we state that citizenship is the "right to have rights", it is evident that human being may have new demands (as in fact happens in several parts of the globe), regarding national, regional and universal rights. 
8. Taking into account the development of the logic of human rights protection, we may infer the persistence of the new forms of exercising citizenship, that are encompassed on the universalist context in a complementary and integrative way. This way, it becomes possible to the individual to reclaim its citizenship on the domestic field of its State (national scope), regional field (for instance, before the Interamerican Court of Human Rights or the European Court of Human Rights) and universally (for instance, before the UN Human Rights Committee)

9. We must pay attention to this vision of complementarity of the protective systems and their role on the fulfillment of citizenship. Since the present citizenship encompasses all human rights, from the international standpoint, and the fundamental rights, from the States' point of view, different spheres of judicialization are attached, as are being placed before the choice of the contemporary citizen. Thus, the possibilities of exercising multiple citizenships or multilateral ones, strengthening even more the process of enforcement of human rights.

\section{REFERENCES}

ARAÚJO, Luiz Alberto David; NUNES, Vidal Serrano. Curso de Direito Constitucional. 9. ed., São Paulo: Editora Saraiva, 2005.

ARENDT, Hannah. The origins of totalitarianism. Nova York: Harcourt Brace Jovanovitch, 1993.

BARZOTTO, Luiz Fernando. Pessoa e reconhecimento - uma análise estrutural. In: ALMEIDA FILHO, Agassiz; MELGARÉ, Plínio (Orgs.). Dignidade da Pessoa Humana - fundamentos e critérios interpretativos. São Paulo: Malheiros Editores, 2010.

BASTOS, Celso. Curso de Direito Constitucional. 22. ed., São Paulo: Editora Saraiva, 2001.

BITTAR, Eduardo C. B. Hermenêutica e Constituição: a dignidade da pessoa humana como legado à pós-modernidade. In: ALMEIDA FILHO, Agassiz; MELGARÉ, Plínio (Orgs.). Dignidade da Pessoa Humana - fundamentos e critérios interpretativos. São Paulo: Malheiros Editores, 2010.

BITTAR, Eduardo C. B. O direito na pós-modernidade e reflexões frankfurtianas. 2. ed., Rio de Janeiro: Forense Universitária, 2009.

BOBBIO, Norberto. A era dos direitos. Tradução de Carlos Nelson Coutinho. Rio de Janeiro: Campus, 1992.

BODIN, Jean. Lex Six Livres de La Republique. Paris: Librairie Générale Française, 1993.

BONAVIDES, Paulo. Revista do Instituto dos Advogados Brasileiros, Rio de Janeiro, ano XXXIV, n. 92, abr./jun. 2000.

COMPARATO, Fabio Konder. A afirmação histórica dos direitos humanos. São Paulo: Saraiva, 1999. 
COMPARATO, Fabio Konder. Ética, direito, moral e religião no mundo moderno. São Paulo: Companhia das Letras, 2006.

CUNHA, Paulo Ferreira. Constituição Viva: cidadania e direitos humanos. Porto Alegre: Livraria do Advogado, 2007.

DALLARI, Dalmo de Abreu. Direitos humanos e Cidadania. 2. ed., São Paulo: Moderna, 2004.

HÄBERLE, Peter. Derecho Constitucional Común Europeo. Tradução de E. Mikunda. In: PÉREZ LUÑO, Antonio Enrique (Coord.). Derechos humanos y constitucionalismo ante el Tercer Milenio. Madrid: Marcial Pons, 1996.

HÄBERLE, Peter. Estado constitucional cooperativo. Trad. Marcos Maliska e Lisete Antoniuk. Porto Alegre: Livraria do Advogado, 2007.

HOBBES, Thomas. Do cidadão. São Paulo: Martins Fontes, 2002.

KANT, Immanuel. Fundamentos da metafísica dos costumes. São Paulo: Ediouro, 2000.

LAFER, Celso. A reconstrução dos direitos humanos: um diálogo com o pensamento de Hannah Arendt. São Paulo: Companhia das Letras, 1988.

LINDGREN ALVES, José Augusto. Cidadania, Direitos Humanos e globalização. In: PIOVESAN, Flavia (org.). Direitos Humanos, globalização econômica e integração regional: desafios do direito constitucional internacional. São Paulo: Max Limonad, 2002.

MALISKA, Marcos Augusto. A cooperação internacional para os direitos humanos entre o direito constitucional e o direito internacional: Desafios ao Estado Constitucional Cooperativo. Revista Forense, Rio de Janeiro, v. 391, p. 627-635, mai./jun. 2007.

MARSHALL, T. H. Cidadania, classe social e status. Rio de Janeiro: Zahar, 1967.

MARX, Karl. Para a questão judaica. São Paulo: Expressão Popular, 2009.

NADER, Paulo. Introdução ao estudo do direito. 24. ed., Rio de Janeiro: Forense, 2004.

PÉREZ LUÑO, A. E. La universidad de los derechos y el Estado constitucional. Bogotá: Universidade Externado de Colombia, 2002.

PÉREZ LUÑO, A. E. La tercera generación de derechos humanos. Navarra: Thomson-Aranzadi, 2006.

PÉREZ LUÑO, A. E. Derechos humanos, Estado de derecho y Constituición. 8. ed. Madrid: Tecnos, 2003.

PINSKY, Jaime; PINSKY, Carla B. (Orgs.) História da cidadania. São Paulo: Contexto, 2003.

ROUSSEAU, Jean-Jacques. O Contrato Social. Rio de Janeiro: Ediouro, 1992.

SARLET, Ingo Wolfgang. Dignidade da pessoa humana e direitos fundamentais. Porto Alegre: Livraria do Advogado, 2001. 
SCHAFER, Jairo. Classificação dos direitos fundamentais - do sistema geracional ao sistema unitário. Porto Alegre: Livraria do Advogado. 2005.

SILVEIRA, Vladmir Oliveira. Direitos Humanos e Desenvolvimento. Palestra proferida nas Faculdades Metropolitanas Unidas - FMU, no dia 13 de agosto de 2008, dentro da semana jurídica que aconteceu entre os dias 11 e 15 de agosto de 2008.

SILVEIRA, Vladmir Oliveira; CONTIPELLI, Ernani. Direitos Humanos Econômicos na perspectiva da Solidariedade: desenvolvimento integral. In: XVI Encontro Nacional CONPEDI, 2008, Salvador BA. Anais XVI Encontro Nacional do CONPEDI, 2008.

SOUSA SANTOS, Boaventura de (Org.) A globalização e as ciências sociais. 3. ed., São Paulo: Cortez, 2005.

SOUSA SANTOS, Boaventura de. Pela mão de Alice. O social e o político na pós-modernidade. São Paulo: Cortez, 2006.

TORRES, Ricardo Lobo. A cidadania multidimensional na era dos direitos. In: TORRES, Ricardo Lobo. Teoria dos direitos fundamentais. Rio de Janeiro: Renovar, 2006.

VIEIRA, Liszt. Cidadania e Globalização. 8. ed. Rio de Janeiro: Record, 2005. 